\title{
A mobile swabbing booth to address Singapore GPs' concerns about swabber protection: human-centred design during the COVID-19 pandemic
}

\author{
Boon See Teo ${ }^{1,2,3,4^{*}}$, Esther $\mathrm{Li}^{1}$, Yi-Lin Khoo ${ }^{5}$, Michelle Evaristo ${ }^{5}$, Yang Fang ${ }^{2}$ and Helen E. Smith ${ }^{2}$
}

\begin{abstract}
Background: During the COVID-19 pandemic, the Ministry of Health asked Singapore's private general practitioners (GPs) to perform swab testing in their clinics, but some GPs had concerns about swabber protection. Our aim was to develop a swabbing booth to address these concerns.

Methods: We developed a prototype with potential GP users using a human-centred design approach and piloted it with $10 \mathrm{GP}$ clinics. The pilot was then extended to $170 \mathrm{GP}$ clinics around Singapore. These GPs were then surveyed on user satisfaction.

Results: Ninety-three GPs (54\%) responded. The majority (75\%) practiced in public residential estates in small practices (mean 1.95 doctors). 86\% requested the booth to enhance swabber protection. 74\% "would recommend" or "would strongly recommend" the booth to colleagues. $79 \%$ continue to use the booth to conduct swab tests. 92\% liked that it offered swabber protection. $71 \%$ liked that the booth created a separate space for swabbing and $64 \%$ liked its ease of disinfection. $47 \%$ started swabbing only after receiving the booth and $58 \%$ said the booth was "important" or "very important" to their decision to participate in swab testing. However, 34\% disliked that it took up too much space and the most frequently critiqued area was the gloves.
\end{abstract}

Conclusion: The human-centred design approach generated a product that had high user satisfaction, addressed GPs' concerns of swabber protection and increased GPs' participation in swab testing. The booth may be useful where GPs are concerned about swabber protection and space is limited.

Keywords: Quality improvement, Safety management, Ergonomics, Infection control, Primary Health Care, Pandemic, Swabbing booth, Safety, COVID-19

*Correspondence: drteobs@gmail.com

1 Camry Medical Centre, 95 Toa Payoh Lorong 4 \#01-66,

Singapore 310095, Singapore

Full list of author information is available at the end of the article

(c) The Author(s) 2021, corrected publication 2021. Open Access This article is licensed under a Creative Commons Attribution 4.0 International License, which permits use, sharing, adaptation, distribution and reproduction in any medium or format, as long as you give appropriate credit to the original author(s) and the source, provide a link to the Creative Commons licence, and indicate if changes were made. The images or other third party material in this article are included in the article's Creative Commons licence, unless indicated otherwise in a credit line to the material. If material is not included in the article's Creative Commons licence and your intended use is not permitted by statutory regulation or exceeds the permitted use, you will need to obtain permission directly from the copyright holder. To view a copy of this licence, visit http://creativecommons.org/licenses/by/4.0/. The Creative Commons Public Domain Dedication waiver (http://creativecommons.org/publicdomain/zero/1.0/) applies to the data made available in this article, unless otherwise stated in a credit line to the data. 


\section{Introduction}

Private general practitioners (GPs) are in the frontline of Singapore's response to the COVID-19 pandemic. There are 1700 private GP clinics in Singapore, which provide $80 \%$ of Singapore's primary care [1]. Mostly situated in residential estates, they are the point of first contact in the health system for most patients. About 930 of these clinics are designated Public Health Preparedness Clinics (PHPCs) [2] and they provide subsidised treatment, investigations and medications during public health emergencies [3].

Upper respiratory tract infections make up $44 \%$ of GPs' acute caseloads [4]. Beginning in January 2020, GPs were asked to refer suspected cases of COVID-19 to hospitals for swab testing. Amid rising daily cases in March 2020, the Ministry of Health encouraged PHPCs to participate in the Swab-and-Send Home (SASH) Programme, which aimed to expand disease surveillance and support rapid case finding [5]. PHPCs on SASH would offer patients with acute respiratory illness same-day COVID-19 swab testing within the clinic. However, GPs were concerned about swabber protection and premise contamination as patients often coughed or sneezed while being swabbed. In April 2020, around 140 out of 930 PHPCs had joined the programme [2].

There are few studies about transmission risk during nasopharyngeal or oropharyngeal swabs [6]. However, it is reasonable to assume that the transmission risk to swabber is high, as during swabbing the potentially infectious patient stands less than a metre away, his face is exposed, and he may cough. These three factors multiply the risk to many times that of a typical interaction with masks worn, more than a metre apart and without coughing $[7,8]$. Furthermore, as SARS-CoV-2 transmission is via droplets, aerosols and fomites, and transmission risk is greater in confined spaces [9], there may be risks to other users of the space, raising the issue of disinfection.

Infection control guidelines for COVID-19 swab testing generally specify that Personal Protective Equipment (PPE) be worn to protect the healthcare worker [10-13]; however, PPE itself can be soiled or fit poorly. The guidelines specified additional measures such as designating a separate area or room for swabbing [10-12], disinfection of the space [10], a physical barrier between patient and swabber [12] or even patient self-swabbing [11].

Swabbing booths were a potential solution to the problem of infection control. These had been deployed to enhance protection for swabbers in various settings both locally [14] and internationally [15-17], but to our knowledge, none in the GP setting. A swabbing booth is able to designate a separate easy-to-disinfect swabbing area with a physical barrier between patient and healthcare worker. The Temasek Foundation (TF), a Singaporean philanthropic organization, collaborated with a PHPC, Camry Medical Centre (CMC), and a precision engineering company, Applied Total Control Treatment Pte Ltd. (ATC), to design and build a swabbing booth that would address the safety concerns of PHPC GPs.

We followed human-centred design (HCD) principles to develop the prototype. HCD is defined by psychologist Donald Norman as "the process that ensures that the designs match the needs and capabilities of the people for whom they are intended" [18]. It is characterised by iterative cycles of observation of users, idea generation, prototyping and user testing.

Our goal was to design a swabbing booth that addressed the GPs' concerns about swabber protection and to evaluate user satisfaction.

\section{Method}

The project had 3 phases: design development, piloting and user survey. We started the design development on 14th May 2020 and closed the survey on 24th September 2020.

Design development (Phase 1) involved 4 GP testers ( 2 male, 2 female) from 3 PHPCs. Discussions and trials involving the GP testers, ATC engineers, and TF volunteers were conducted at a PHPC (CMC). The GPs reviewed preliminary prototypes and defined 6 functional requirements for a booth (see Table 1): swabber protection, ease of disinfection, outdoor use, mobility, good ergonomics and patient privacy.

Subsequently, CMC, TF and ATC developed the design in 3 iterations, each involving:

- Idea generation: CMC translated the GP testers' inputs into a design drawing.

- Prototyping: ATC built a prototype based on the design drawing.

- Testing: The completed prototypes were tested onsite in CMC. GP testers role-played as swabber and patient, performing pretend swabs to test booth ergonomics, and provided feedback. Patients were not involved in testing at this stage.

- Observation: TF and CMC consolidated the feedback. Design decisions were then translated into a final design drawing. Table 1 summarises the design strategies.

In all, five prototypes of booths and four models of gloves were tested. The final booth design (see Fig. 1 and Fig. 2) had separate cubicles for swabber and patient. It was mobile and slim enough to go through doorways, and light enough to be moved by one person. We chose a model of gloves that fulfilled testers' requirements for 
Table 1 Key user requirements and design strategies

\section{GPs' requirements}

\section{Design strategies adopted}

\section{Swabber protection}

- A full-height cubicle served as a barrier between patient and swabber, Swabbers should be protected from droplets produced by coughing and sneezing during swabbing.

\section{Ease of disinfection}

Wipe-down had to be simple as the booth would be disinfected between patients.

\section{Outdoor or semi-outdoor use}

GPs should be able to place it outside the clinic to segregate swabbing space from consultation space, for infection control.

\section{Mobility}

with a roof to block upward transmission trajectory.

- The joints of the structure were sealed to prevent droplet transmission.

- For the panels, polycarbonate was chosen over acrylic as polycarbonate

could withstand wipe-downs with alcohol.

- Surfaces were made as smooth as possible with no nooks and crannies.

- Aluminium and polycarbonate were chosen for their weather-resistance.

- No electrical components were included.

- The cubicles were open, without doors, to allow wind, humidity, heat and sunlight to combat pathogens. This would also reduce the number of surfaces needing wipe-down between patients.

- Castors and handles were added.

In order to be stored indoors after hours, it had to be sufficiently compact to fit within small clinic spaces, and require minimal manpower to set up as GP clinics run on lean teams.

- was made narrow enough to pass through standard doorways.

- The footprint was made just large enough to contain both swabber and patient $(600 \times 800 \mathrm{~mm})$

- Lightweight materials and compact size made it easy for a single clinic staff to move and set up.

\section{Good ergonomics}

It should be comfortable for the swabber to perform the procedure. It should also accommodate patients of different builds.

- Dimensions were specified for a standing swabber performing a nasopharyngeal swab on a patient $1.10-1.75 \mathrm{~m}$ tall. Shorter patients could stand on a stool and taller patients could be seated.

- Glove ports were fixed at a comfortable height for testers who were

$1.55-1.75 \mathrm{~m}$ tall.

- Gloves had to be touch-sensitive, low cost and easy to replace.

- Curved shelves in both cubicles provided space for swabbing equipment to be placed.

Patient privacy

If the swabbing was done outside the clinic in a public area, patient privacy had to be respected.

- Semi-opaque cubicles for swabber and patient provided some privacy while allowing light to pass through for swabbing.

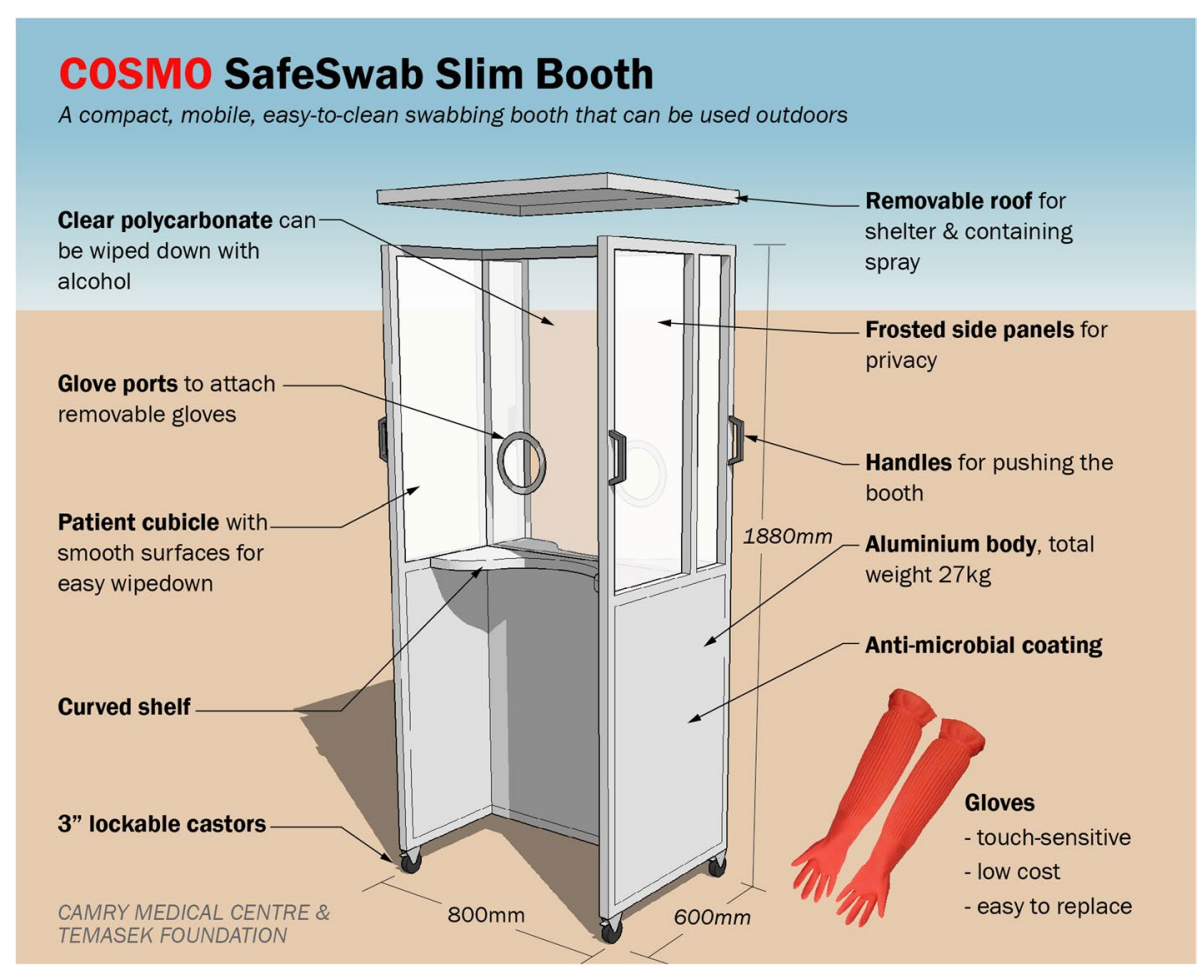

Fig. 1 Final design of mobile swabbing booth 


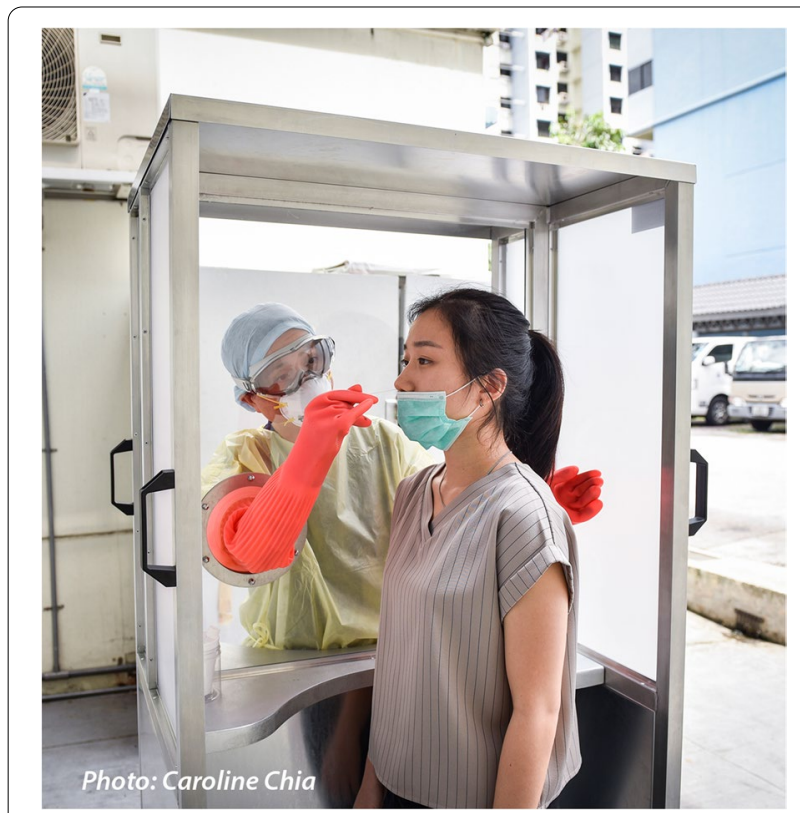

Fig. 2 Photograph of the booth
Table 2 Characteristics of respondents $(n=93)$

\begin{tabular}{lll}
\hline & $\mathbf{n}(\%)$ & Mean (SD) \\
\hline Age & & - \\
$30-39$ & $23(25 \%)$ & - \\
$40-49$ & $28(30 \%)$ & - \\
$50-59$ & $35(38 \%)$ & - \\
$60-69$ & $6(6 \%)$ & - \\
70 and above & $1(1 \%)$ & - \\
Type of practice & & - \\
Solo clinic & $45(48 \%)$ & - \\
Group of 2-9 clinics & $31(33 \%)$ & $1.95(1.20)$ \\
Group of 10 or more clinics & $17(18 \%)$ & $4.52(2.68)$ \\
Number of doctors in clinic & - & - \\
Number of clinic support staff & - & - \\
Location of GP clinic & & - \\
public residential estate & $70(75 \%)$ & - \\
shopping mall & $13(14 \%)$ & - \\
private residential estate & $4(5 \%)$ & - \\
office building & $5(5 \%)$ & - \\
industrial estate & $1(1 \%)$ & - \\
\hline
\end{tabular}

ref. no. IRB-2020-07-031). Informed consent was also obtained from the subjects of the photo in Fig. 2 for it to be published in an online open-access publication.

Descriptive statistics (i.e., frequencies, percentages, mean, SD) were used to summarize the respondents' sociodemographics and practice characteristics; Chisquare tests of association was used to examine the association between categorical variables; Pearson's correlation was used to examine association between continuous variables; independent samples t-test was used to examine differences between groups. All analyses were performed in SPSS for Windows, version 22.0 [19].

\section{Results}

A total of 170 GPs received the swabbing booth and the survey link. 54\% of the GPs responded $(n=93)$, of whom $91 \%(n=85)$ completed the entire survey. The number of respondents answering each question is indicated in the tables.

\section{Characteristics of the respondents and their practices}

As seen in Table 2, the GPs spanned a wide age range and majority $(75 \%)$ practiced in public residential estates in small practices (mean $=1.95$ doctors).

\section{Primary findings on user experience: reasons for booth application and booth satisfaction}

The primary findings are summarised in Table 3. The top 3 reasons for applying for the booth were: to increase 
Table 3 Primary findings on user experience

\begin{tabular}{|c|c|}
\hline & $\mathrm{n}(\%)$ \\
\hline Reasons for applying for booth (multiple selections accepted) & $(n=92)^{\mathrm{a}}$ \\
\hline I felt it would be safer for the swabber & $79(86 \%)$ \\
\hline I felt it would make the disinfection process easier & $60(65 \%)$ \\
\hline It was provided free of charge & $51(55 \%)$ \\
\hline I did not have the necessary equipment to conduct a swab test (e.g. table, privacy screen) & $29(32 \%)$ \\
\hline I felt it would provide privacy for the patients & $28(30 \%)$ \\
\hline Other (reduced patient anxiety, save time without having to wear full PPE, wanted designated work area for swabbing outside clinic) & $4(4 \%)$ \\
\hline Are you currently using the booth to conduct swab tests? & $(n=86)^{a}$ \\
\hline Yes & $68(79 \%)$ \\
\hline No, I swab without the booth now & $16(19 \%)$ \\
\hline No, I have stopped conducting swab tests in my clinic & $2(2 \%)$ \\
\hline How likely are you to recommend the booth to another colleague? & $(n=85)^{a}$ \\
\hline Will strongly recommend & $34(40 \%)$ \\
\hline Will recommend & $29(34 \%)$ \\
\hline Neutral & $15(18 \%)$ \\
\hline Will not recommend & $6(7 \%)$ \\
\hline Strongly will not recommend & $1(1 \%)$ \\
\hline What do you like about the booth? (multiple selections accepted) & $(n=87)^{\mathrm{a}}$ \\
\hline It provides protection to the swabber & $80(92 \%)$ \\
\hline It creates a separate space for swabbing & $62(71 \%)$ \\
\hline It makes the disinfection process easier and quicker & $56(64 \%)$ \\
\hline It is easy to move around & $44(51 \%)$ \\
\hline It is easy to conduct swab tests using the booth & $41(47 \%)$ \\
\hline It provides privacy to the patient & $36(41 \%)$ \\
\hline Others: & $2(2 \%)$ \\
\hline What do you not like about the booth? (multiple selections accepted) & $(n=86)^{a}$ \\
\hline Others (e.g. gloves, glove port height) & $38(44 \%)$ \\
\hline Takes up too much space & $29(34 \%)$ \\
\hline Difficult to conduct swab tests using the booth & $27(31 \%)$ \\
\hline Difficult to disinfect & $14(16 \%)$ \\
\hline Troublesome to set up and store & $14(16 \%)$ \\
\hline Inadequate patient privacy & $12(14 \%)$ \\
\hline Inadequate swabber protection & $1(1 \%)$ \\
\hline Were you swabbing patients prior to receiving the booth? & $(n=92)^{a}$ \\
\hline Yes & $49(53 \%)$ \\
\hline No & $43(47 \%)$ \\
\hline How important was getting the booth in your decision to participate in Swab-and-Send-Home (SASH)? & $(n=92)^{a}$ \\
\hline Very important & $32(35 \%)$ \\
\hline Important & $21(23 \%)$ \\
\hline Somewhat important & $23(25 \%)$ \\
\hline Not important & $16(17 \%)$ \\
\hline
\end{tabular}

${ }^{\mathrm{a}}=$ number of respondents who answered this question

swabber protection (86\%), ease of disinfection (65\%) and provided for free $(55 \%)$.

We assessed overall satisfaction by whether the GPs were still using the booth at the time of the survey and whether they would recommend it to other GPs. We also assessed satisfaction towards individual attributes of the booth, with questions on likes, dislikes and ergonomics. 
Table 4 Exploratory analyses of factors associated with user experience

\begin{tabular}{|c|c|c|c|}
\hline \multicolumn{4}{|l|}{ Likes and dislikes correlated with continued booth use } \\
\hline & $\begin{array}{l}\text { Currently swabbing with booth } \\
(n=68)\end{array}$ & $\begin{array}{l}\text { Currently swabbing without booth } \\
(n=16)\end{array}$ & $p$-value \\
\hline \multicolumn{4}{|l|}{ Likes: } \\
\hline - It creates a separate space for swabbing & $53(78 \%)$ & $7(44 \%)$ & $0.006^{\mathrm{a}}$ \\
\hline - It is easy to move around & $38(56 \%)$ & $4(25 \%)$ & 0.026 \\
\hline - It is easy to conduct swab tests using the booth & $40(59 \%)$ & $0(0 \%)$ & $<0.001$ \\
\hline - It provides protection for the swabber & $65(96 \%)$ & $13(81 \%)$ & $0.045^{\mathrm{a}}$ \\
\hline - It provides privacy to the patient & $33(49 \%)$ & $3(19 \%)$ & 0.030 \\
\hline - It makes the disinfection process easier and quicker & $47(69 \%)$ & $7(44 \%)$ & $0.057^{\mathrm{a}}$ \\
\hline \multicolumn{4}{|l|}{ Dislikes: } \\
\hline - It takes up too much space & $18(26 \%)$ & $10(63 \%)$ & $0.006^{\mathrm{a}}$ \\
\hline - Difficult to conduct swab tests using the booth & $13(19 \%)$ & $14(88 \%)$ & $<0.001$ \\
\hline - Difficult to disinfect & $10(15 \%)$ & $4(25 \%)$ & 0.320 \\
\hline - Troublesome to set up and store & $7(10 \%)$ & $7(44 \%)$ & $0.001^{\mathrm{a}}$ \\
\hline - Inadequate patient privacy & $7(10 \%)$ & $4(25 \%)$ & 0.117 \\
\hline - Inadequate swabber protection & $0(0 \%)$ & $1(6 \%)$ & $0.038^{\mathrm{a}}$ \\
\hline Commented on gloves & $22(32 \%)$ & $4(25 \%)$ & 0.567 \\
\hline Commented on glove ports & $9(13 \%)$ & $4(25 \%)$ & 0.242 \\
\hline \multicolumn{4}{|c|}{ Note. Chi-square tests of associations were performed for all analyses. Results in bold are statistically significant } \\
\hline \multicolumn{4}{|c|}{ a some cells have expected count less than 5} \\
\hline \multicolumn{4}{|l|}{ Comparison of users $<50$ years old and $\geq 50$ years old } \\
\hline & $<50$ years old $(n=50)$ & $\geq 50$ years old $(n=42)$ & p-value \\
\hline & n (\%) or Mean (SD) & & \\
\hline Currently using the booth & $36(72 \%)$ & $32(76 \%)$ & 0.252 \\
\hline Not swabbing prior to receiving booth & $18(36 \%)$ & $25(60 \%)$ & 0.024 \\
\hline Total number of likes & $3.45(1.74)$ & $4.13(1.34)$ & 0.044 \\
\hline Total number of dislikes & $1.47(1.25)$ & $1.74(1.33)$ & 0.326 \\
\hline $\begin{array}{l}\text { How important was getting the booth to your decision to partici- } \\
\text { pate in SASH? ( } 1=\text { not important; } 4=\text { very important })\end{array}$ & $2.64(1.17)$ & $2.88(1.04)$ & 0.305 \\
\hline $\begin{array}{l}\text { How likely are you to recommend the booth? }(1=\text { will strongly } \\
\text { recommend; } 5=\text { strongly will not recommend) }\end{array}$ & $2.04(1.07)$ & $1.85(0.88)$ & 0.361 \\
\hline
\end{tabular}

Note. Chi-square tests of associations were performed for the analyses involving currently using the booth and not swabbing prior to receiving the booth. Independent samples t-tests were performed for all other analyses

\section{Exploratory analyses of factors associated with user experience}

In addition, we performed exploratory analyses (see Table 4) to investigate factors associated with continued use of the booth, ergonomics evaluations, and importance of the booth to participating in swab testing.

To explore the effect of age on user experience, we also compared responses of users under 50 years old with those 50 years and above. We hypothesized that age influenced users' attitudes towards the use of swabbing booth as the 50-59 age group supplied the highest percentage of respondents (38\%), followed by 40-49 (30\%), then 30-39 (25\%). 50years old was chosen as a cutoff as it created two subgroups of similar size. Only $7 \%$ of respondents were 60 years and older, possibly because retirement age in Singapore is 62 years old and many GPs may have retired by that age. Thus, we grouped those 60 and over together with the 50-59 year olds for the analysis.

$79 \%$ of respondents continued using the booth to conduct COVID-19 swabs at the time of filling out the survey. $74 \%$ of respondents said that they "would recommend" or "would strongly recommend" the booth to colleagues.

Top three features of the booth which the GPs liked were swabber protection (92\%), creation of a separate space for swabbing (71\%) and ease of disinfection (64\%). We compared those who continued to use the booth to swab and those who were swabbing without the booth (see Table 4). Those who continued to use the booth were more likely to indicate their appreciation for the ease of moving the booth around ( $56 \%$ vs $25 \%, p=0.026$ ), ease of swabbing $(59 \%$ vs $0 \%, p<0.001)$ and the patient privacy it 
provided ( $49 \%$ vs $19 \%, p=0.030$ ). They were less likely to indicate they disliked the difficulty of conducting a swabbing test in the booth $(19 \%$ vs $88 \%, \mathrm{p}<0.001)$.

Top dislikes were that it took up too much space (34\%), difficulty in swabbing (31\%) and difficulty in disinfecting (16\%).

Ergonomics was rated as either poor, adequate or excellent. $56 \%$ of the GPs rated the ergonomics of the booth as adequate, $23 \%$ excellent and $21 \%$ poor. Poorer ratings were correlated with GPs' heights falling outside the range of $160-180 \mathrm{~cm}(p=0.033)$ and the user making free-text comments on the glove ports $(p=0.010)$, but not about the gloves $(p=0.630$, all Pearson chisquare). Poorer ratings on ergonomics were correlated with selecting the dislike of difficulty in swabbing $(p=0.001$, Pearson chi-square) and number of total dislikes $(p<0.001)$.

$47 \%$ of the GPs were not swabbing prior to receiving the booth. $58 \%$ of the GPs said the booth was "important" or "very important" to their decision to participate in the SASH programme.

Rating of importance to participation in SASH was correlated with the reason for applying for the booth because the GP did not have the necessary equipment (Pearson correlation $p=0.002$ ). It was also correlated with liking the swabber protection $(p=0.005)$, ease of disinfection $(p=0.004)$, ease of conducting swab tests $(p<0.001)$, mobility of the booth $(\mathrm{p}=0.002)$ and patient privacy $(p=0.034)$.

A significantly higher proportion of GPs 50 years and above $(60 \%)$ were not swabbing before receiving the booth, compared to the younger GPs (36\%) (Pearson chisquare $p=0.024)$. Respondents over 50 years tended to indicate more likes than those below 50 (Total number of likes was 4.13 vs 3.45 , 2-tailed significance $p=0.050$ ).

\section{Patterns of use}

$52 \%$ of GPs swabbed outdoors or semi-outdoors. $85 \%$ of GPs swabbed $\leq 5$ patients a day and $96 \%$ of the swabs were done by doctors. Swabbers wore N95 masks (94\%), isolation gowns (97\%), gloves (96\%) and eye protection gear $(75 \%)$ and $56 \%$ changed items of PPE after every swab. Booths were disinfected by clinic assistants (76\%) and most often with alcohol (75\%). $74 \%$ reported that the booth required only one person to move it around.

Table 5 Themes in free text comments on the booth

\begin{tabular}{|c|c|c|}
\hline Theme & Sub-theme & Examples \\
\hline \multirow[t]{8}{*}{ Gloves (35) } & Prefer to swab without long gloves [9] & $\begin{array}{l}\text { "I cut off the hands of the gloves as it was time consuming and difficult to use with } \\
\text { the gloves" }\end{array}$ \\
\hline & Wrong size [7] & "supplied gloves too small. Not used as a result." \\
\hline & Not touch-sensitive enough [6] & "glooves [sic] thick and lac [sic] 'feel"," "hand gloves are too stiff" \\
\hline & Generally hard to use [6] & "The full length rubber glove that came with booth hard to use" \\
\hline & Tear easily [5] & "Some difficulty applying gloves onto the booth - the gloves tear easily" \\
\hline & Hard to insert/remove hands [4] & $\begin{array}{l}\text { "the gloves are too rigid, VERY hard to even get my hands in, granted that I have big } \\
\text { hands, size } 8\end{array}$ \\
\hline & Slippery [3] & "The gloves are slippery and makes handling poor." \\
\hline & Hard to change gloves [1] & "Gloves that can be easily fitted and changed" \\
\hline \multirow[t]{3}{*}{$\begin{array}{l}\text { Accommodating } \\
\text { different-sized users } \\
{[20]}\end{array}$} & Height \& restrictiveness of glove port [16] & $\begin{array}{l}\text { "Booth is not user friendly as there is a restriction in terms of height due to the fixed } \\
\text { location of the hand glove position. it restricts the height of both the swabber and } \\
\text { patients" }\end{array}$ \\
\hline & Could not swab sitting/wheelchair patients [6] & "it is not wheelchair or elderly friendly." \\
\hline & Cubicle too small or short [2] & $\begin{array}{l}\text { "however, the top of the booth is too low for Caucasian patients" } \\
\text { "For a ladies [sic] frame it's a good fit but not for the larger built guys" }\end{array}$ \\
\hline \multirow[t]{3}{*}{ Dimensions [19] } & Too bulky/wanted foldable [10] & $\begin{array}{l}\text { "Try to design a foldable one." } \\
\text { "no need to be so bulky and tall" }\end{array}$ \\
\hline & Patient cubicle dimensions [3] & "Too far for patient. Patient can move away during swab." \\
\hline & Too heavy [3] & "heavy to push in and out of the clinic after every session" \\
\hline \multirow[t]{3}{*}{ Miscellaneous [19] } & Want it more enclosed [6] & $\begin{array}{l}\text { "There is no "door" to total close patient in so to ensure the aerosol particles are } \\
\text { contain within the booth..." }\end{array}$ \\
\hline & Enhance places to put things [5] & $\begin{array}{l}\text { "Put a ledge on patients' side so the things less likely to drop" } \\
\text { "compartments to put disinfectants and swabbing materal [sic]" }\end{array}$ \\
\hline & Others [8] - 2 or fewer comments per theme & $\begin{array}{l}\text { "Difficult for patient to hear me while swabbing - I bought a mic and speaker set to } \\
\text { overcome this" }\end{array}$ \\
\hline
\end{tabular}




\section{Users' free text comments on booth design}

$55 \%$ of the GPs made free text comments on the booth (see Table 5). Analysis was carried out by two of the authors. Main critiques were on the gloves, height of glove ports and the bulkiness of the booth.

Seven respondents expressed appreciation for the booth. One memorable compliment was from an elderly GP:

"I am very grateful for the booth, without which I would not have started doing the swab. The peace of mind it gives me is tremendous, as I am already 67 and have co morbidity as well. Hence the swab booth gives me the opportunity to help in the fight against Covid. Thank you again."

\section{Discussion}

As of 14 November 2020 there were 379 GPs publicly listed as being on the SASH programme [21]. Our study found that 170 GPs had requested a swabbing booth. Around half (47\%) of the respondents only started swabbing after receiving the booth, suggesting that the booth helped to increase GP participation in swab testing. Around three-quarters of the users were satisfied with the booth with $79 \%$ of the GPs continuing to use it and $74 \%$ who would recommend it. Majority of the GPs liked the swabber protection (92\%), creation of a separate space for swabbing (71\%) and ease of disinfection (64\%). $74 \%$ of the GPs reported that the booth required only one person to move it, suggesting that our booth design had achieved the objectives of being mobile, lightweight and easy to set up. The survey highlighted some areas of user dissatisfaction: $34 \%$ felt the booth took up too much space; $21 \%$ rated the ergonomics as poor. Free-text comments often criticized the gloves, height of glove ports and bulkiness of the booth.

\section{Our swabbing booth in context}

During the COVID-19 pandemic, swabbing booths have been developed in countries such as India [20,22], South Korea [16, 23], the United States [24-26], and Singapore [14] where they have been deployed in settings such as hospitals or testing centres. To our knowledge, ours is the only booth in medical literature designed by GPs for use in GP clinics and deployed on this scale (170 clinics). Ours is the second project to incorporate a user satisfaction survey; one other booth project has reported a 9-question user survey of 8 users.

In terms of form, available swabbing booths can be broadly divided into two types, pressurized and nonpressurized. Pressurized booths [16, 22-25] are sealed cubicles with electrical ventilation and air-cleaning systems. Non-pressurized booths $[14,15,26]$ are open-sided structures which are naturally ventilated. Whether pressurized or non-pressurized, both types tend to be large, stationary boxes to contain one standing person. Our booth was an open, non-pressurized, naturally ventilated booth but with unique features not found in other designs: it was compact, designed to be wheeled around by one person, and contained cubicles for swabber and patient which provided some privacy. These were ideas generated by testers during the human-centred design process.

\section{Human-centred design in a pandemic}

We found the human-centred design approach valuable as it generated a product that GPs met the needs of the GPs, increased their participation in swabbing and thus expanded community surveillance for COVID-19. This approach also encouraged innovation and yielded a novel booth design well adapted to the local context.

Due to its iterative nature the human-centred design process can be time-consuming, and even Donald Norman has acknowledged that it can create scheduling problems [27]. However, we were able to progress quickly from design to working product in 2 weeks, and this was partly due to the time saved by having the GP end users co-design the booth while an engineering team rapidly prototyped the design. Other swabbing booths have also been co-designed by clinicians $[14,16,26]$, while an alternative approach was design led by engineering teams [20, $22,24,25]$. In our situation, we found that having GP end users co-design was efficient and direct and resulted in a product that was well-received by GP end users.

\section{Areas of user dissatisfaction}

The survey highlighted certain areas of user dissatisfaction such as booth size, glove port height and gloves. At the design stage, we had already considered these issues but were limited by time, movement and resource constraints during a national lockdown. There was urgency to complete the design in two weeks to be in time for the lifting of the lockdown that we anticipated would increase demand for community swab testing. Under those circumstances, it was difficult to refine the booth further to eliminate user dissatisfaction entirely. There was no immediate solution to making the booth smaller or foldable without compromising the ergonomics or structural integrity. The glove port height was designed for a swabber $1.55-1.75 \mathrm{~m}$ tall but the ports were not height adjustable. Although the gloves were the best of several ready-made products available, they still needed improvement to increase dexterity.

Had there been fewer constraints, a more refined booth may have been achieved, perhaps with a choice of sizes and adjustable-height glove ports. It is interesting that 
in the other booth project which involved a user survey [24], users rated the booth highly on safety $(10 \pm 0.00$ out of a maximum of 10), but rated it most poorly on dexterity of gloves $(6.37 \pm 2.13$ out of 10$)$. This could suggest a need for more research into purpose-built long swabbing gloves.

\section{Relationship of user satisfaction and user participation in the design process}

User satisfaction has been linked to user participation in the design process and user-developer communication [28]. The first 10 pilot GP testers understood the constraints as they had been closely communicating with the design team. Thus, they did not expect a perfect product. However, when the final booth was delivered to 170 practices working independently, it became a "ready-to-use" product. The rest of the 170 GPs were now the consumers, so they may have had higher expectations and therefore expressed more dissatisfaction. On reflection, we recognise that user satisfaction could have been improved by giving attention to creating documentation that communicated the booth features to users and setting up user networks where feedback could be rapidly addressed.

\section{Learning about booth users}

The survey revealed insights on the group of GPs motivated to take up the booth. These were PHPC GPs practicing in small clinics in public residential estates, concerned about swabber protection, disinfection, cost and proper equipment. Despite being supplied PPE, they still requested a swabbing booth, and more than half changed items of PPE after every swab, suggesting an acute consciousness of infection control. Among these GPs, 50 to 59-year-olds constituted the largest group. Those 50 years old and above were significantly less likely to be swabbing before receiving the booth and indicated more likes for the booth. Future studies could survey this group of GPs on their knowledge, attitudes and perceptions towards infection control, and the findings may be used to shape public policy and medical device design.

\section{Limitations}

The 170 GPs represent around one-sixth of the 930 PHPC GPs. The recruited GPs were from established GP networks (e.g. College of Family Physicians Singapore, Primary Care Networks), and their views may not reflect those of PHPC GPs in general. As we did not survey the GPs who did not apply for the booth, we were unable to study the reasons for not applying for the booth and whether this was due to dissatisfaction with the design or due to other reasons. Replicating the study in a different time and place may not produce similar user satisfaction results if other forms of swabber protection were readily available. We also acknowledge that the small sample size and multiple testing may increase the likelihood that significant results may be due to chance.

\section{Conclusion}

The human-centred design approach generated a product that yielded user satisfaction, addressed GPs' concerns of swabber protection and increased GPs' participation in swab testing. The booth may be useful in settings where GPs are concerned about swabber protection and space is limited.

\footnotetext{
Abbreviations

GP: General Practitioner; HCD: Human-centred design; PHPC: Public Health Preparedness Clinic; PCN: Primary Care Network; SASH: Swab-and-Send-Home; TF: Temasek Foundation; CMC: Camry Medical Centre; ATC: Applied Total Control Treatment Pte Ltd..
}

\section{Supplementary Information}

The online version contains supplementary material available at https://doi. org/10.1186/s12875-021-01531-8.

Additional file 1.

\section{Acknowledgements}

We would like to acknowledge the following for their contributions to this paper: Teo Hui Keng (Associate Director, Temasek International); Sam Xin Hui (Research Associate, Lee Kong Chian School of Medicine, Nanyang Technological University).

We would also like to acknowledge the following for their contributions to the booth project: Temasek Foundation; College of Family Physicians Singapore; the Primary Care Networks; Marcus Sia, Lim Heng Chye and Vivien Tan from Applied Total Control Treatment Pte Ltd.; Michelle Tiong, Loh Kengli and Jenny Lim from Camry Medical Centre; Dr. Tham Tuck Seng; Dr. Jean Yim; Dr. Alex Wong; Dr. Gregory Leong; Dr. Gregory Yim; Dr. Seow En Hao; Dr. Qing Manli; Dr. Ng Joon Hwee; Dr. Jasmine Hui and Dr. Hing Siong Chen.

\section{Guideline statement}

All methods were carried out in accordance with relevant guidelines and legislations.

\section{Authors' contributions}

TBS contributed to the booth and survey designs, analysed and interpreted the survey data, and substantively drafted the work. EL contributed to the booth and survey designs, interpreted the data, and substantively drafted the work. KYL contributed to the booth and survey designs, facilitated booth production, recruited participants, interpreted the data, and substantively drafted the work. ME contributed to the booth and survey designs, recruited participants and edited the work. FY analysed and interpreted the data and edited the work. HES contributed to the survey design, analysed and interpreted the data and edited the work. All have approved the submitted version.

\section{Authors' information}

TBS is a practicing general practitioner from Camry Medical Centre. She holds various academic appointments including a membership in Lee Kong Chian School of Medicine's Primary Care Research Network. EL is employed in Camry Medical Centre as a project manager. ME and KYL are employees of Temasek International but volunteered on this project under Temasek Foundation.

FY is a Research Fellow at Lee Kong Chian School of Medicine. HES is a Professor of Family Medicine \& Primary Care at Lee Kong Chian School of Medicine, and the Director of their Primary Care Research Network. 


\section{Funding}

Temasek Foundation funded the production of the swabbing booths. Lee Kong Chian School of Medicine, Nanyang Technological University, provided the Qualtrics and SPSS software.

\section{Availability of data and materials}

All data generated or analysed during this study are available at https://doi. org/10.21979/N9/XRTKJV.

\section{Declarations}

\section{Ethics approval and consent to participate}

The study had ethics approval from Nanyang Technological University (NTUIRB reference number IRB-2020-07-031). Informed consent was taken from all participants.

\section{Consent for publication}

Informed consent for publication has been obtained in writing from the individuals pictured in Fig. 2.

\section{Competing interests}

The authors KYL and ME were employees of Temasek International but volunteered on this project under Temasek Foundation. None of the authors received any compensation from Temasek Foundation.

\section{Author details}

${ }^{1}$ Camry Medical Centre, 95 Toa Payoh Lorong 4 \#01-66, Singapore 310095, Singapore. ${ }^{2}$ Lee Kong Chian School of Medicine, Nanyang Technological University, Experimental Medicine Building, 59 Nanyang Drive, Singapore 636921, Singapore. ${ }^{3}$ Yong Loo Lin School of Medicine, National University of Singapore, NUS Yong Loo Lin School of Medicine NUHS Tower Block, 1E Kent Ridge Road Level 11, Singapore 119228, Singapore. ${ }^{4}$ Duke-NUS Medical School, 8 College Road, Singapore 169857, Singapore. ${ }^{5}$ Temasek International, 60B Orchard Road, \#06-18 Tower 2, The Atrium@Orchard, Singapore 238891, Singapore.

\section{Received: 14 November 2020 Accepted: 24 August 2021}

Published online: 08 September 2021

\section{References}

1. Ministry of Health Singapore. $\mathrm{MOH}$ | Primary Healthcare Services. https:// www.moh.gov.sg/home/our-healthcare-system/healthcare-services-andfacilities/primary-healthcare-services. Accessed 22 Oct 2020.

2. COVID-19: More than 4,500 swab tests performed at polyclinics, GP clinics to date, says MOH. Channel NewsAsia. Available from: https://www. channelnewsasia.com/news/singapore/covid-19-swab-tests-polyclinicsgp-moh-12633978. Accessed 14 Nov 2020.

3. Government Technology Agency. Flu Go Where - FAQ. http://flu.gowhere. gov.sg/faq. Accessed 22 Oct 2020

4. Ministry of Health Singapore. Primary Care Survey 2014. Ministry of Health Singapore; 201416 p. Available from: https://www.moh.gov.sg/docs/libra riesprovider5/resources-statistics/reports/moh-primary-care-survey-2014report.pdf.

5. Ministry of Health Singapore. $\mathrm{MOH}$ | News Highlights. https://www. moh.gov.sg/news-highlights/details/steady-progress-in-dormitoryclearance-aggressive-testing-and-tracing-in-phase-2. Accessed $22 \mathrm{Oct}$ 2020.

6. Agarwal A, Fernando S, Honarmand K, Bakaa L, Brar S, Granton D, et al. Risk of dispersion or aerosol generation and infection transmission with nasopharyngeal and oropharyngeal swabs for detection of COVID-19: a systematic review. BMJ Open. 2021;11(3):e040616.

7. Chu D, AkI E, Duda S, Solo K, Yaacoub S, Schünemann H, et al. Physical distancing, face masks, and eye protection to prevent person-to-person transmission of SARS-CoV-2 and COVID-19: a systematic review and meta-analysis. Lancet. 2020;395(10242):1973-87.

8. Li H, Leong F, Xu G, Kang C, Lim K, Tan B, et al. Airborne dispersion of droplets during coughing: a physical model of viral transmission. Scientific Reports. 2021;11(1):4617.
9. Coronavirus disease (COVID-19): How is it transmitted?. Who.int. 2021 [cited 11 May 2021]. Available from: https://www.who.int/news-room/qa-detail/coronavirus-disease-covid-19-how-is-it-transmitted

10. Infection Control Guidance. cdc.gov. 2021 [cited 11 May 2021]. Available from: https://www.cdc.gov/coronavirus/2019-ncov/hcp/infection-contr ol-recommendations.html

11. Department of Health and Social Care UK. Standard Operating Procedures and Guidance for Covid-19 PCR Testing in General Practice. Crown; 2018 p. 8-9. Available from: https://assets.publishing.service.gov.uk/government/ uploads/system/uploads/attachment_data/file/932670/Standard_opera ting_procedures_for_COVID-19_PCR_testing_in_general_practice.pdf

12. European Centre for Disease Prevention and Control. Infection prevention and control and preparedness for COVID-19 in healthcare settings Sixth update. Stockholm: ECDC; 2021. Available from: https://www.ecdc. europa.eu/sites/default/files/documents/Infection-prevention-and-contr ol-in-healthcare-settings-COVID-19_6th_update_9_Feb_2021.pdf

13. Australian Government. ICEG Guidance on the use of personal protective equipment (PPE) for non-inpatient health care and specimen collection, during the COVID-19 outbreak - Version 8 (19/11/20). Australian Government; 2020 p. 6-7.

14. Tan Z, Khoo D, Zeng L, Tien J, Lee A, Ong Y et al. Protecting health care workers in the front line: Innovation in COVID-19 pandemic. J Global Health. 2020;10(1):010357

15. The 'phone booths' that are making Covid tests in India easier, quicker and safer. The Economic Times. https://economictimes.indiatimes.com/ industry/healthcare/biotech/healthcare/the-phone-booths-that-aremaking-covid-tests-in-india-easier-quicker-and-safer/articleshow/75040 280.cms. Accessed 22 Oct 2020.

16. Kim A. South Korea's 'walk-thru' coronavirus testing booth goes global. The Korea Herald Available from: https://www.straitstimes.com/asia/ east-asia/south-koreas-walk-thru-coronavirus-testing-booth-goes-global. Accessed 22 Oct 2020.

17. Eglash R. What happened when I went to a coronavirus testing booth. Wash Post 2020. Available from: https://www.washingtonpost.com/ world/middle_east/what-happened-when-i-went-to-a-coronavirus-testi ng-booth/2020/04/26/f5471de2-865f-11ea-81a3-9690c9881111_story. html. Accessed 22 Oct 2020.

18. NormanD. The Design of Everyday Things. New York: Basic Books; 2013.

19. Corp IBM. IBM SPSS statistics for windows, version 22.0. Armonk: IBM Corp; 2013.

20. Joshi J. COVSACK: an innovative portable isolated and safe COVID-19 sample collection kiosk with automatic disinfection. Trans Indian National Acad Eng. 2020;5(2):269-75.

21. Government Technology Agency. Flu Go Where. https://flu.gowhere.gov. sg. Accessed 14 Nov 2020.

22. Nair S, Prajapati A, Venkatesan R, Vayalappil M, Kishore A. Design and evaluation of Chitra swab collection booths for health professionals in COVID-19 pandemic. Trans Indian National Acad Eng. 2020. https://doi. org/10.1007/s801090000086.

23. Kim S, Lee J. Walk-Through Screening Center for COVID-19: an Accessible and Efficient Screening System in a Pandemic Situation. J Korean Med Sci. 2020;35(15):e154

24. Aroom K, Ge J, Al-Zogbi L, White M, Trustman A, Greenbaum A et al. Positive Pressure Testing Booths Development and Deployment In Response To The COVID-19 Outbreak [preprint]. 2021 [cited 11 May 2021]. Available from: https://arxiv.org/pdf/2102.11997.pdf

25. Garmat develops booth for COVID-19 coronavirus testing - Repairer Driven News. Repairer Driven News. 2021 [cited 9 July 2021]. Available from: https://www.repairerdrivennews.com/2020/04/13/garmat-devel ops-booth-to-aid-covid-19-coronavirus-testing/

26. Transforming the Way Clinicians Test COVID-19 Patients. Brigham Health Hub. 2021 [cited 9 July 2021]. Available from: https://brighamhealthhub. org/transforming-the-way-clinicians-test-covid-19-patients/

27. NormanD. The Design of Everyday Things. p327. New York: Basic Books; 2013.

28. McKeen J, Guimaraes T, Wetherbe J. The relationship between user participation and user satisfaction: an investigation of four contingency factors. MIS Q. 1994;18(4):427.

\section{Publisher's Note}

Springer Nature remains neutral with regard to jurisdictional claims in published maps and institutional affiliations. 